Artikel Penelitian

\title{
Pengaruh Penambahan Pegagan (Centela asiatica L. Urban) terhadap Daya Terima dan Mutu Kerupuk
}

The Influence of Centella asiatica (L) Urban Addition to the Acceptability and Quality of Crackers

Adelianda Auliani Kamaruddin Nur ${ }^{{ }^{*}}$, Mazarina Devi ${ }^{2}$, Laili Hidayati ${ }^{2}$

${ }^{1}$ Program Studi S1 Pendidikan Tata Boga, Universitas Negeri Malang

${ }^{2}$ Jurusan Teknologi Industri, Fakultas Teknik Universitas Negeri Malang

*Korespondensi dengan penulis (adeliandaauliani@gmail.com)

Artikel ini dikirim pada tanggal 4 Februari 2017 dan dinyatakan diterima tanggal 14 Juli 2017. Artikel ini juga dipublikasi secara online melalui

www.jatp.ift.or.id. Hak cipta dilindungi undang-undang. Dilarang diperbanyak untuk tujuan komersial.

Diproduksi oleh Indonesian Food Technologists® @2017

\begin{abstract}
Abstrak
Pegagan merupakan tanaman yang mengandung senyawa-senyawa yang baik untuk kesehatan. Penelitian ini bertujuan untuk mengetahui sifat fisik (warna, daya kembang, daya patah), tingkat kesukaan (rasa, warna, dan kerenyahan), mutu hedonik (rasa dan kerenyahan) dan sifat kimia (protein, lemak, kadar air, kadar abu, serat kasar, asam asiatik) kerupuk pegagan dengan penambahan pegagan $10 \%, 20 \%$ dan $30 \%$, serta mengetahui formula terbaik kerupuk pegagan. Penelitian yang dilakukan adalah penelitian eksperimen menggunakan Rancangan Acak Lengkap dengan tiga perlakuan dan dua kali pengulangan. Data hasil analisis diuji secara statistik menggunakan uji ANOVA dilanjutkan dengan uji Duncan's. Perlakuan terbaik ditentukan menggunakan metode indeks efektivitas. Hasil penelitian menunjukkan bahwa kandungan kimia yang terdapat pada pegagan yaitu protein $4,05 \%$, lemak $0,35 \%$, air $85,46 \%$, abu $6,064 \%$, serat kasar $8,89 \%$, asam asiatik $63,7 \%(\mathrm{mg} / 100 \mathrm{~g})$. Perbedaan formulasi kerupuk pegagan berpengaruh terhadap sifat fisik (warna, daya kembang dan daya patah), uji kesukaan, uji mutu hedonik, dan sifat kimia (protein, lemak, kadar air, kadar abu, serat kasar, asam asiatik). Formula terbaik yang diperoleh yaitu kerupuk pegagan dengan penambahan pegagan $10 \%$. Sifat fisik warna yang diperoleh yaitu warna tingkat kecerahan (L) 66,110, warna tingkat kemerahan $(a+)+4,605$, warna tingkat kekuningan $(b+)+60,085$, daya kembang 558,856 dan daya patah 0,02355 . Tingkat Kesukaan rasa sebesar 3,83, tingkat kesukaan warna sebesar 3,57, tingkat kesukaan kerenyahan sebesar 4. Mutu hedonik rasa sebesar 4,29, mutu hedonik kerenyahan sebesar 4,19 . Sifat kimia yang diperoleh yaitu protein $6,07 \%$, lemak $0,5 \%$, kadar air $9,04 \%$, kadar abu 2,35\%, serat kasar 1,34\%, asam asiatik 0,42 (mg/ $100 \mathrm{~g})$.
\end{abstract}

Kata kunci: asam asiatik, kerupuk pegagan, mutu kerupuk, pegagan, penerimaan

\section{Abstract}

Centella asiatica is a plant which has good compounds for health. This research aim to know physical feature (color, expand power and fracture power), predilection level (taste, color and crispy), quality of hedonism (taste and crispy) and chemistry feature (protein, fat, water level, ash level, fiber crude and asiatic acid) Centella asiatica crackers by adding Centela Asiatica 10\%, 20\% and 30\% and also knowing the best formula of Centella asiatica crackers as wel. This research was conducted using completely randomized design with three different treatments and twice repetition. The data of the analysis result was examined statistically using ANOVA test and Duncan's test. The best treatment was then determined by using method of effectiveness index. The finding showed that the chemical contents in Centella asiatica were protein $4,05 \%$, fat 0,35\%, water $85.46 \%$, sawdust $6.064 \%$, fiber crude $8.89 \%$ and asiatic acid 63.7 ( $\mathrm{mg} / 100 \mathrm{~g})$. The difference of Centella asiatica crackers formulation influential toward physical feature (color, expand power and fracture power), predilection test, quality of hedonism test and proximat analysis (protein, fat, water level, sawdust level, fiber crude, asiatik acid). The Addition of $10 \%$ Centella asiatica was being the best formula which was acquired. Phisycal feature of color which was acquired the color of brightness level $(L) 66.110$, the color of florid level $(a+)+4.605$, the color of yellowish $(b+)+60.085$, expand power 558.856, fracture power 0.02355. The level of taste predilection was 3.83, the level of color predilection was 3.57 , the level of crispy predilection was 4 . The hedonism quality of taste was 4.29 , the hedonism quality of crispy was 4.19 . Chemistry feature were protein $6.07 \%$, fat $0.5 \%$, water level $9.04 \%$, ash level $2.35 \%$, fiber crude $1.34 \%$, asiatic acid 0.42(mg/100g).

\section{Keywords: asiatic acid, Centella asiatica crackers, crackers quality, Centella asiatica, acceptance}

\section{Pendahuluan}

Pegagan merupakan tanaman yang memiliki beberapa kandungan gizi dan kaya akan manfaat. Pegagan berfungsi membersihkan darah, melancarkan peredaran darah, peluruh kencing, penurun panas, menghentikan pendarahan, meningkatkan syaraf memori, antibakteri, tonik, antiplasma, antiinflamasi, hipotensif, insektisida, antialergi dan simultan (Lasmadiwati, 2003). Pegagan merupakan salah satu tanaman obat yang dikenal dalam literatur India memiliki aktivitas terhadap sistem saraf pusat, sebagai tonik saraf, penguat daya ingat dan kecerdasan. Berdasarkan uji klinis di India, pegagan mampu meningkatkan IQ, prestasi akademis dan konsentrasi (Ambika et al. 2014).

Kerupuk merupakan produk makanan kering yang populer dan sudah lama dikenal masyarakat Indonesia. Hampir di semua lapisan masyarakat menggemari kerupuk, karena harganya terjangkau dan 
mudah diperoleh (Rosiani, 2011). Kerupuk termasuk jenis makanan yang sangat digemari, oleh anak-anak maupun orang dewasa (Sahriman, 2004). Selain dikonsumsi masyarakat dalam negeri, kerupuk ikan juga telah diekspor ke luar negeri. Berdasarkan data Badan Pusat Statistik volume ekspor kerupuk Indonesia tahun 2015 pada bulan November mencapai 767.965 $\mathrm{kg}$ dengan nilai FOB 2.022.485 (US \$)dan kumulatif bulan Januari-November sebesar $7.719 .973 \mathrm{~kg}$ dengan nilai FOB 19.812.335 (US \$).

Penelitian ini meneliti tentang sifat fisik (warna, daya kembang, daya patah), tingkat kesukaan (rasa, warna, dan kerenyahan), mutu hedonik (rasa dan kerenyahan) dan sifat kimia (protein, lemak, kadar air, kadar abu, serat kasar, asam asiatik) kerupuk pegagan dengan penambahan pegagan $10 \%, 20 \%$ dan $30 \%$, serta mengetahui formula terbaik kerupuk pegagan.

\section{Materi dan Metode \\ Materi}

Bahan pembuatan kerupuk pegagan adalah daun pegagan, tepung tapioka, tepung terigu, ikan layang, garam, bawang putih, dan soda kue. Bahan analisis meliputi $\mathrm{H}_{2} \mathrm{SO}_{4}, \mathrm{Na}_{2} \mathrm{SO}_{4}-\mathrm{HgO}(20: 1), \mathrm{NaOH}$, $\mathrm{NaS}_{2} \mathrm{O}_{2}$, Indikator metil merah dan metil biru, $\mathrm{HCl}$ $0,02 \mathrm{~N}, \mathrm{H}_{2} \mathrm{BO}_{2} 4 \%$, Aquades, Pelarut Heksana, dan Natrium, Metanol 95\%, dan silika gel.

\section{Metode}

Penelitian meliputi proses pembuatan kerupuk pegagan, analisis protein (semi mikro kjeldal), lemak (soxhlet), kadar air (termogravimetri), kadar abu (gravimetri), serat kasar (hidrolisis asam basa), asam asiatik (HPLC), warna (collor reader), daya kembang, daya patah (hardness test), uji hedonik (rasa, warna, dan kerenyahan) dan uji mutu hedonik (rasa dan kerenyahan) serta penentuan perlakuan terbaik dengan perhitungan indeks efektifitas yang mengacu pada metode deGarmo (1984).

\section{Prosedur Pembuatan Kerupuk}

Prosedur penelitian dilakukan dengan membuat kerupuk pegagan dengan penambahan pegagan $10 \%$, $20 \%, 30 \%$. Bahan dalam pembuatan kerupuk disiapkan dan ditimbang sesuai resep yang telah ditentukan, selanjutnya pegagan dihaluskan menggunakan blender dengan ditambah air 30\% hingga menjadi puree pegagan. Ikan, bawang putih dan garam dihaluskan hingga lembut. Tepung tapioka $25 \%$ dan air 50\% dipanaskan hingga tergelatinisasi membentuk bubur tapioka. Setelah bubur tapioka dingin, puree pegagan, dan adonan ikan dicampur hingga rata. Sisa tepung tapioka, tepung terigu dan air ditambahkan sedikitsedikit diaduk hingga adonan kalis. Pencetakan dilakukan dengan membetuk adonan menjadi silinder dibungkus dengan daun pisang yang diolesi dengan minyak dan disemati lidi pada bagian atas dan bawah adonan. Proses pengukusan dilakukan selama 90 menit dengan suhu $80^{\circ} \mathrm{C}-90^{\circ} \mathrm{C}$. Adonan kerupuk yang telah dikukus didinginkan dalam refrigerator selama 18 jam dengan suhu $4^{\circ} \mathrm{C}$ agar menjadi kaku.Pengirisan dilakukan menggunakan pisau atau alat pemotong lain. Adonan kerupuk diiris dengan ketebalan $2 \mathrm{~mm}$. Pengeringan dilakukan dengan cabinet dryer selama 10 jam dengan suhu $50^{\circ} \mathrm{C}$.

Kerupuk yang telah kering selanjutnya digoreng dalam frying pan pada suhu $175-185^{\circ} \mathrm{C}$ selama $25-60$ detik

\section{Analisis Statistik}

Data yang diperoleh dianalisis dengan metode One-Way ANOVA menggunakan SPSS 16.0 Statistic Software. Level signifikan yang ditetapkan sebesar $a=$ 0,05 .

\section{Hasil dan Pembahasan}

Karakteristik Bahan Baku (Pegagan)

Pada Tabel 1. Sifat kimia daun pegagan segar hasil analisis dengan literatur menunjukkan nilai yang berbeda. Kandungan protein, abu dan serat kasar hasil analisis lebih besar dari literatur, sedangkan kadar lemak, air, dan asam asiatik hasil analisis lebih rendah dari literatur. Menurut Arsyaf (2012) perbedaan kandungan gizi pegagan dapat dipengaruhi oleh perbedaan metode analisis yang digunakan, jenis pegagan, dan tempat pengambilan pegagan. Sedangkan menurut Mora dan Fernando (2012), kandungan kimia tanaman pegagan salah satunya dapat dipengaruhi oleh berbagai faktor seperti kesuburan tanah, kecukupan air, kelembaban udara, dan intensitas cahaya matahari yang didapat pada

Tabel 1. Hasil Uji Kimia (Proksimat) Daun Pegagan

\begin{tabular}{cccc}
\hline \multirow{2}{*}{ No. } & Sifat Kimia & \multicolumn{2}{c}{ Jumlah } \\
\cline { 3 - 4 } & Protein \% & Hasil Analisis & 1,6 \\
2 & Lemak \% & 4,05 & 0,6 \\
3 & Air \% & 0,35 & 89,3 \\
4 & Abu \% & 85,46 & 1,6 \\
5 & Serat Kasar\% & 6,064 & 2,0 \\
6 & Asam Asiatik (mg/100g) & 8,89 & 66,0 \\
\hline
\end{tabular}

Tabel 2. Hasil Uji Sifat Fisik Kerupuk Ikan dengan Penambahan Pegagan

\begin{tabular}{cccc}
\hline Parameter & \multicolumn{3}{c}{ Penambahan Pegagan } \\
\cline { 2 - 4 } & $10 \%$ & $20 \%$ & $30 \%$ \\
Warna $(\mathrm{L})$ & 66,110 & 62,530 & 57,520 \\
Warna $(\mathrm{a}+)$ & $+4,605$ & $+5,840$ & $+6,180$ \\
Warna $(\mathrm{b}+)$ & $+60,085$ & $+54,245$ & $+47,350$ \\
Daya Kembang & 558,856 & 412,990 & 342,6445 \\
Daya Patah & 0,0236 & 0,024 & 0,02455 \\
\hline
\end{tabular}


daerah tersebut. Perbedaan ini biasanya berpengaruh kepada kondisi metabolisme tumbuhan dan metabolit sekunder.

Warna

Warna Tingkat Kecerahan (L) Kerupuk Pegagan

Rerata warna tingkat kecerahan (L) kerupuk pegagan yang disajikan dalam Tabel 2. berkisar antara 57,520 - 62,530. Tingkat kecerahan kerupuk pegagan menurun dengan bertambahnya komposisi pegagan. Kerupuk pegagan dengan penambahan pegagan $10 \%$ memiliki nilai warna tingkat kecerahan tertinggi yaitu sebesar 62,530. Sedangkan penambahan pegagan $30 \%$ memiliki nilai warna tingkat kecerahan terendah yaitu 57,520. Analisis ragam menunjukkan bahwa penambahan pegagan yang berbeda berpengaruh nyata $(a=5 \%)$ pada tingkat kecerahan kerupuk pegagan.

Warna Tingkat Kemerahan (a+) Kerupuk Pegagan pegagan $10 \%$ memiliki nilai warna tingkat kekuningan tertinggi yaitu sebesar $+60,085$. Sedangkan penambahan pegagan $30 \%$ memiliki nilai warna tingkat kekuningan terendah yaitu $+47,350$.

Analisis ragam menunjukkan bahwa penambahan pegagan yang berbeda berpengaruh nyata $(\mathrm{a}=5 \%)$ pada tingkat kemerahan kerupuk pegagan. Analisis ragam menunjukkan bahwa penambahan pegagan yang berbeda berpengaruh nyata $(a=5 \%)$ pada tingkat kekuningan kerupuk pegagan.

\section{Daya Kembang}

Rerata daya kembang kerupuk pegagan yang disajikan dalam Tabel 2. berkisar antara 342,6445 558,856 . Daya kembang kerupuk pegagan menurun dengan bertambahnya komposisi pegagan. Kerupuk pegagan dengan penambahan pegagan $10 \%$ memiliki nilai daya kembang tertinggi yaitu sebesar 558,856. Sedangkan penambahan pegagan $30 \%$ memiliki nilai daya kembang terendah yaitu 342,6445. Analisis ragam menunjukkan bahwa penambahan pegagan yang berbeda berpengaruh nyata $(a=5 \%)$ pada daya kembang kerupuk pegagan. Daya kembang kerupuk dipengaruhi oleh pati, banyaknya penambahan bahan bukan pati maka pengembangan kerupuk semakin kecil. Menurut Afifah dan Anjani (2008), makin banyak penambahan bahan bukan pati, makin kecil
Rerata warna tingkat kemerahan $(a+)$ kerupuk pegagan yang disajikan dalam Tabel 2 . berkisar antara $+4,605-+6,180$. Tingkat kemerahan kerupuk pegagan meningkat dengan bertambahnya komposisi pegagan. Kerupuk pegagan dengan penambahan pegagan $30 \%$ memiliki nilai warna tingkat kemerahan tertinggi yaitu sebesar $+6,180$. Sedangkan penambahan pegagan $10 \%$ memiliki nilai warna tingkat kemerahan terendah yaitu $+4,605$. Analisis ragam menunjukkan bahwa penambahan pegagan yang berbeda berpengaruh nyata $(a=5 \%)$ pada tingkat kemerahan kerupuk pegagan.

\section{Warna Tingkat Kekuningan $(b+)$ Kerupuk Pegagan}

Rerata warna tingkat kekuningan $(b+)$ kerupuk pegagan yang disajikan dalam Tabel 2. berkisar antara $+47,350$ - $+60,085$. Tingkat kekuningan kerupuk pegagan menurun dengan bertambahnya komposisi pegagan. Kerupuk pegagan dengan penambah

pengembangan kerupuk pada saat penggorengan. Semakin banyak pati pada adonan maka adonan lebih mudah tergelatinisasi (Koswara, 2009).

\section{Daya Patah}

Rerata daya patah kerupuk pegagan yang disajikan dalam Tabel 2. berkisar antara 0,02355 0,02455 . Daya patah kerupuk pegagan meningkat dengan bertambahnya komposisi pegagan. Kerupuk pegagan dengan penambahan pegagan 30\% memiliki nilai daya patah tertinggi yaitu sebesar 0,02455 . Sedangkan penambahan pegagan $10 \%$ memiliki nilai daya patah terendah yaitu 0,02355. Analisis ragam menunjukkan bahwa penambahan pegagan yang berbeda berpengaruh nyata $(a=5 \%)$ pada daya patah kerupuk pegagan. Daya patah kerupuk dipengaruhi oleh kandungan pati yang terdapat pada kerupuk pegagan. Kandungan pati pada kerupuk pegagan terdapat pada tepung tapioka. Menurut Mulyana et al. (2014), semakin tinggi kandungan pati dalam adonan maka proses gelatinisasi semakin baik, sehingga semakin besar pengembangan produk yang dihasilkan, hal ini menyebabkan daya patah semakin rendah.

\section{Hedonik dan Mutu Hedonik Kerupuk Pegagan}

Pengujian organoleptik merupakan cara pengujian menggunakan indera manusia sebagai alat utama untuk mengukur daya terima terhadap makanan.

Tabel 3. Hasil Uji Organoleptik Kerupuk dengan Penambahan Pegagan

\begin{tabular}{|c|c|c|c|c|}
\hline \multirow{2}{*}{\multicolumn{2}{|c|}{ Parameter }} & \multicolumn{3}{|c|}{ Penambahan Pegagan } \\
\hline & & $10 \%$ & $20 \%$ & $30 \%$ \\
\hline \multirow[t]{3}{*}{ Uji Hedonik } & Rasa & $\begin{array}{c}3,83 \\
\text { (agak suka) }\end{array}$ & $\begin{array}{c}3,46 \\
\text { (biasa) }\end{array}$ & $\begin{array}{c}3,29 \\
\text { (biasa ) }\end{array}$ \\
\hline & Warna & $\begin{array}{c}3,57 \\
\text { (agak suka) }\end{array}$ & $\begin{array}{c}3,4 \\
\text { (biasa) }\end{array}$ & $\begin{array}{c}\text { 3,33 } \\
\text { (biasa) }\end{array}$ \\
\hline & Kerenyahan & $\begin{array}{c}4 \\
\text { (agak suka) }\end{array}$ & $\begin{array}{c}\text { 3,9 } \\
\text { (agak suka) }\end{array}$ & $\begin{array}{c}3,76 \\
\text { (agak suka) }\end{array}$ \\
\hline \multirow[t]{2}{*}{$\begin{array}{l}\text { Uji Mutu } \\
\text { Hedonik }\end{array}$} & Rasa & $\begin{array}{c}4,29 \\
\text { (agak gurih) }\end{array}$ & $\begin{array}{c}3,71 \\
\text { (agak gurih) }\end{array}$ & $\begin{array}{c}3,49 \\
\text { (cukup gurih) }\end{array}$ \\
\hline & Kerenyahan & $\begin{array}{c}\text { 4,19 } \\
\text { (agak renyah) }\end{array}$ & $\begin{array}{c}3,91 \\
\text { (agak renyah) }\end{array}$ & $\begin{array}{c}3,67 \\
\text { (agak renyah) }\end{array}$ \\
\hline
\end{tabular}


Analisis ini dilakukan pada 35 orang panelis. Tingkat kesukaan panelis dan mutu kerupuk pegagan (Tabel 3.) menurun dengan bertambahnya komposisi pegagan. Analisis ragam menunjukkan bahwa penambahan pegagan yang berbeda berpengaruh nyata $(a=5 \%)$ pada organoleptik kerupuk pegagan.

Rasa kerupuk pegagan dipengaruhi oleh zat vellarin yang tedapat pada pegagan memberi rasa pahit. Semakin banyak pegagan yang ditambahkan maka zat vellarin pada kerupuk pegagan semakin banyak. Zat vellarine yang terkandung dalam pegagan memberikan rasa pahit.

Warna pada kerupuk pegagan dipengaruhi oleh zat tanin dan klorofil pada daun pegagan, sehingga semakin banyak pegagan yang ditambahkan maka kerupuk pegagan memiliki warna hijau kecoklatan semakin gelap. Menurut Lestari et al. (2013) tanin merupakan zat pewarna yang menimbulkan warna cokelat atau kecokelatan. Klorofil yang berwarna hijau dapat berubah menjadi hijau kecoklatan dan mungkin berubah menjadi cokelat akibat substitusi magnesium oleh hidrogen membentuk feofitin (klorofil yang kehilangan magnesium).

Kerenyahan pada kerupuk pegagan dipengaruhi oleh kandungan pati. Penambahan bahan bukan pati yang terlalu banyak dapat menurunkan kerenyahan kerupuk. Pati mempunyai dua komponen utama, yaitu amilosa (fraksi terlarut) dan amilopektin (fraksi tidak terlarut), amilopektin merupakan salah satu komponen pati yang dapat mempengaruhi daya kembang kerupuk dan berfungsi memberikan sifat renyah pada kerupuk.

\section{Protein Kerupuk Pegagan}

Rerata protein kerupuk pegagan berkisar antara $6,07 \%-6,56 \%$. Protein kerupuk pegagan meningkat dengan bertambahnya komposisi pegagan. Kerupuk pegagan dengan penambahan pegagan $30 \%$ memiliki protein tertinggi yaitu sebesar $6,56 \%$. Sedangkan penambahan pegagan $10 \%$ memiliki protein terendah yaitu 6,07. Analisis ragam menunjukkan bahwa penambahan pegagan yang berbeda berpengaruh nyata $(\mathrm{a}=5 \%)$ pada kandungan protein kerupuk pegagan. Kandungan protein pada pegagan dipengaruhi oleh komposisi penambahan pegagan dan ikan layang. Menurut hasil analisi kandungan protein pegagan yaitu 4,05. Menurut DKBM (2005), ikan layang mengandung protein sebesar $22 \%$. Penambahan ikan layang bertujuan untuk menstandartkan mutu kerupuk yang ditetapkan oleh SNI yaitu protein minimal $5 \%$. Penambahan pegagan setiap $10 \%$ menyumbang rata-rata sebesar $0,24 \%$.

Lemak Kerupuk Pegagan

Rerata lemak kerupuk pegagan berkisar antara
0,35\% - 0,50\%. Lemak kerupuk pegagan menurun dengan bertambahnya komposisi pegagan. Kerupuk pegagan dengan penambahan pegagan $10 \%$ memiliki lemak tertinggi yaitu sebesar $0,50 \%$. Sedangkan penambahan pegagan 30\% memiliki lemak terendah yaitu $0,35 \%$. Analisis ragam menunjukkan bahwa penambahan pegagan yang berbeda berpengaruh nyata $(\mathrm{a}=5 \%)$ pada kandungan lemak kerupuk pegagan.

Kandungan lemak pada kerupuk pegagan dipengaruhi oleh kerusakan lemak pada proses pemanasan dan beberapa kandungan kimia pada pegagan. Kerusan lemak pada pembuatan kerupuk pegagan diakibatkan karena proses pengukusan dan pengeringan dengan oven. Menurut Edwar et al. (2011), pemanasan dengan suhu tinggi dan lama dapat menyebabkan kerusakan asam lemak tidak jenuh sehingga membentuk asam lemak jenuh dan berbagai jenis gugus radikal bebas. Kandungan ekstrak pegagan seperti asiatikosid, flavonoid dan triterpenoid diketahui memiliki efek antioksidan. Antioksidan dikenal sebagai zat yang dapat menetralisir atau meredam dampak negatif dari radikal bebas (Andriani, 2006).

\section{Kadar Air Kerupuk Pegagan}

Rerata kadar air kerupuk pegagan berkisar antara 9,04\% - 9,94\%. Kadar air kerupuk pegagan meningkat dengan bertambahnya komposisi pegagan. Kerupuk pegagan dengan penambahan pegagan 30\% memiliki kadar air tertinggi yaitu sebesar 9,94\%. Sedangkan penambahan pegagan $10 \%$ memiliki kadar air terendah yaitu $9,04 \%$. Analisis ragam menunjukkan bahwa penambahan pegagan yang berbeda berpengaruh nyata $(a=5 \%)$ pada kadar air kerupuk pegagan. Kadar air kerupuk pegagan dipengaruhi oleh kandungan air pada daun pegagan sangat besar. Menurut hasil analisis daun pegagan segar mengandung kadar air sebesar $85,46 \%$.

\section{Kadar Abu Kerupuk Pegagan}

Rerata kadar abu kerupuk pegagan berkisar antara $2,35 \%-3,01 \%$. Kadar abu kerupuk pegagan meningkat dengan bertambahnya komposisi pegagan. Kerupuk pegagan dengan penambahan pegagan 30\% memiliki kadar abu tertinggi yaitu sebesar 3,01\%. Sedangkan penambahan pegagan 10\% memiliki kadar abu terendah yaitu $2,35 \%$. Analisis ragam menunjukkan bahwa penambahan pegagan yang berbeda berpengaruh nyata $(a=5 \%)$ pada kadar abu kerupuk pegagan.

\section{Serat Kasar Kerupuk Pegagan}

Rerata serat kasar kerupuk pegagan berkisar antara $1,34 \%-1,77 \%$. Serat kasar kerupuk pegagan

Tabel 4. Hasil Uji Sifat Kimia Kerupuk dengan Penambahan Pegagan

\begin{tabular}{cccc}
\hline Parameter & \multicolumn{3}{c}{ Penambahan Pegagan } \\
\cline { 2 - 4 } & $10 \%$ & $20 \%$ & $30 \%$ \\
\hline Protein & 6,07 & 6,38 & 6,56 \\
Lemak & 0,50 & 0,40 & 0,35 \\
Kadar Air & 9,04 & 9,64 & 9,94 \\
Kadar Abu & 2,35 & 2,69 & 3,01 \\
Serat Kasar & 1,34 & 1,62 & 1,77 \\
Asam Asiatik & 0,42 & 0,47 & 0,53 \\
\hline
\end{tabular}


meningkat dengan bertambahnya komposisi pegagan. Kerupuk pegagan dengan penambahan pegagan $30 \%$ memiliki serat kasar tertinggi yaitu sebesar 1,77\%. Sedangkan penambahan pegagan 10\% memiliki serat kasar terendah yaitu 1,34\%. Analisis ragam menunjukkan bahwa penambahan pegagan yang berbeda berpengaruh nyata $(a=5 \%)$ pada serat kasar kerupuk pegagan. Kadar serat kasar yang terkandung dalam kerupuk pegagan dipengaruhi oleh kandungan serat kasar pada daun pegagan. Menurut hasil analisis serat kasar pada daun pegagan sebesar $8.89 \%$.

\section{Asam Asiatik Kerupuk Pegagan}

Rerata asam asiatik kerupuk pegagan berkisar antara $0,42 \%-0,53 \%$. Asam asiatik kerupuk pegagan meningkat dengan bertambahnya komposisi pegagan. Kerupuk pegagan dengan penambahan pegagan $30 \%$ memiliki asam asiatik tertinggi yaitu sebesar $0,53 \%$. Sedangkan penambahan pegagan 10\% memiliki serat kasar terendah yaitu $0,42 \%$. Analisis ragam menunjukkan bahwa penambahan pegagan yang berbeda berpengaruh nyata $(a=5 \%)$ pada asam asiatik kerupuk pegagan. Asam asiatik yang terkandung dalam kerupuk pegagan dipengaruhi oleh kandungan asam asiatik pada daun pegagan. Menurut hasil analisis kandungan asam asiatik pada pegagan segar sebesar 63,7 (mg/100gr).

\section{Perlakuan Terbaik}

Pemilihan perlakuan terbaik menggunakan metode indeks efektivitas terhadap parameter fisik, organoleptik dan kimia kerupuk pegagan. Data panelis yang telah diperoleh pembobotannya kemudian dilakukan perhitungan menggunakan metode indeks efektivitas atau metode deGarmo.

Formula terbaik yang diperoleh yaitu pada formula kerupuk pegagan dengan penambahan pegagan $10 \%$ dengan nilai total 1,24. Sifat fisik warna tingkat kecerahan (L) 66,110, warna tingkat kemerahan $\left(a^{*}\right)+4,605$, warna tingkat kekuningan $\left(b^{*}\right)+60,085$, daya kembang 558,856, daya patah 0,02355, uji hedonik rasa 3,83 , uji hedonik warna 3,57 , uji hedonik kerenyahan 4 , uji mutu hedonik rasa 4,29 , uji mutu hedonik kerenyahan 4,19 , ), kandungan protein $6,07 \%$, kadar air 9,04\%, asam asiatik 0,42(mg/100 gr), kadar lemak $0,50 \%$, kadar abu 2,35\%, dan serat kasar $1,34 \%$.

\section{Kesimpulan}

Berdasarkan hasil penelitian dan pembahasan tentang "Pengaruh Penambahan Pegagan (Centela asiatica (L.) Urban) terhadap Daya Terima dan Mutu Kerupuk" maka dapat disimpulkan bahwa: kandungan kimia pada daun pegagan segar yaitu protein $4,05 \%$, lemak $0,35 \%$, air $85,46 \%$, abu $6,064 \%$, serat kasar $8,89 \%$. Kandungan bioaktif yaitu asam asiatik 63,7 (mg/100g). Warna tingkat kecerahan (L) tertinggi diperoleh kerupuk pegagan dengan penambahan pegagan $10 \%$ dengan nilai 66,110 . Warna tingkat kemerahan $(\mathrm{a}+)$ tertinggi diperoleh kerupuk pegagan dengan penambahan pegagan $30 \%$ dengan nilai $+6,180$. Warna tingkat kekuningan $(b+)$ tertinggi diperoleh kerupuk pegagan dengan penambahan pegagan $10 \%$ dengan nilai $+60,085$. Daya kembang tertinggi diperoleh kerupuk pegagan dengan penambahan pegagan $10 \%$ dengan nilai 558,856. Daya patah tertinggi diperoleh kerupuk pegagan dengan penambahan pegagan $30 \%$ dengan nilai 0,02455 .

Skor kesukaan rasa tertinggi diperoleh kerupuk pegagan dengan penambahan pegagan $10 \%$ dengan nilai 3,83. Skor kesukaan warna tertinggi diperoleh kerupuk pegagan dengan penambahan pegagan $10 \%$ dengan nilai 3,57. Skor kesukaan kerenyahan tertinggi diperoleh kerupuk pegagan dengan penambahan pegagan $10 \%$ dengan nilai 4,0 . Skor mutu hedonik rasa tertinggi diperoleh kerupuk pegagan dengan penambahan pegagan $10 \%$ dengan nilai 4,29 . Skor mutu hedonik kerenyahan tertinggi diperoleh kerupuk pegagan dengan penambahan pegagan $10 \%$ dengan nilai 4,19 .

Kadar protein tertinggi diperoleh kerupuk pegagan dengan penambahan pegagan 30\% dengan nilai $6,56 \%$. Kadar lemak tertinggi diperoleh kerupuk pegagan dengan penambahan pegagan $10 \%$ dengan nilai $0,50 \%$. Kadar air tertinggi diperoleh kerupuk pegagan dengan penambahan pegagan $30 \%$ dengan nilai $9,94 \%$. Kadar abu tertinggi diperoleh kerupuk pegagan dengan penambahan pegagan $30 \%$ dengan nilai $3,01 \%$. Serat kasar tertinggi diperoleh kerupuk pegagan dengan penambahan pegagan $30 \%$ dengan nilai $1,77 \%$. Kandungan asam asiatik tertinggi diperoleh kerupuk pegagan dengan penambahan pegagan $30 \%$ dengan nilai 0,53 (mg/100gr). Formulasi terbaik diperoleh kerupuk pegagan dengan penambahan pegagan $10 \%$ dengan nilai 1,24 .

\section{Daftar Pustaka}

Afifah, Diana. N., Anjani. G. 2008. Sistem Produksi dan Pengawasan Mutu Kerupuk Udang Berkualitas Ekspor. Seminar Nasional PATPI 2008. Fakultas Kedokteran UNDIP, Semarang.

Ambika. D., Arun Raj GR, Shailaja U, Rao P.N, Santhosh. KCN. 2014. Study on the efficacy of Centella asiatica Linn. on borderline intelligence of 5th standard students of a rural area in Southern India. Journal of Pharmacognosy and Phytochemistry. 2014; (2)5, 120-122.

Andriani, Y. 2007. Uji Aktivitas Antioksidan Ekstrak Betaglukan dari Saccharomyces Cerevisiae. Jurnal Gradien. (3)1, 226-230.

Arsyaf, A. Rizki. 2012. Pembuatan Roti Kering (Bagelen) Pegagan (Centella asiatica) Sebagai Pangan Fungsional Untuk Lansia. Skripsi. Bogor: Departemen Gizi Masyarakat IPB.

Badan Pusat Statistik. 2015. Buletin Perdagangan Luar Negeri.ISSN : 2252-8563.

Badan Standardisasi Nasional. 2009. Persyaratan Mutu dan Keamanan Pangan Kerupuk Ikan. SNI 2713.1: 2009.

De Garmo, E.P., W.G. Sullivan, J.R. Canada. 1984. Engineering Economy. Seventh Edition. Macmillan Pub. Co, New York.

Depkes RI. Daftar Komposisi Bahan Makanan (DKBM). 2005.

Edwar, Z., H. Suyuthie, E. Yerizel, D. Sulastri. 2011. Pengaruh Pemanasan terhadap Kejenuhan Asam Lemak Minyak Goreng Sawit dan Minyak Goreng Jagung. Jurnal Indon Med Assoc., 61(6), 249-252. 
Koswara, Sutrisno. 2009. Pengolahan Aneka Kerupuk. Ebookpangan.com

Lasmadiwati. 2003. Pegagan. Penebar Swadaya, Jakarta.

Lestari, Puji., Wijana, Susinggih, Putri, Widelia Ika. 2013. Ekstraksi Tanin dari Daun Alpukat (Persea Americana Mill.) sebagai Pewarna Alami (Kajian Proporsi Pelarut dan Waktu Ekstraksi). Artikel Ilmiah Teknologi Industri Pertanian, Fakultas Teknologi Pertanian Universitas Brawijaya, Malang.

Mora, Enda., Fernando, Armon. 2012. Optimasi Ekstaksi Triterpenoid Total Pegagan (Centella asiatica (Linn.) Urban yang Tumbuh di Riau. Jurnal Penelitian Farmasi Indonesia, 1(1), 11-16.

Mulyana, Wahono H.S, Indria P. 2014. Pengaruh Proporsi (Tepung Tempe Semangit : Tepung Tapioka) dan Penambahan Air Terhadap Karakteristik Kerupuk Tempe Semangit. Jurnal Pangan dan Agroindustri, 4(2), 113-120.

Rosiani, N. 2011. Pembuatan Kerupuk dengan Fortifikasi Daging Lidah Buaya (Aloe vera) Kaya Antioksidan. Skripsi. Surakarta: Teknologi Hasil Pertanian UNS.

Sahriman. 2004. Cara Membuat Kerupuk. PT Balai Pustaka (Persero), Surabaya. 